\title{
Lack of formation of Reissner fiber leads to hydrocephalus S Rodríguez ${ }^{1}$, LF Bátizi1 , AR Ortloff1 ${ }^{1}$, K Vío ${ }^{1}$, RI Muñoz ${ }^{1}$, LM DeGraff², JP Graves², DJ Stumpo², PJ Blackshear², DC Zeldin², J Goto3 ${ }^{3}$, T Tezuka3 , T Yamamoto ${ }^{3}$ and EM Rodríguez*1
}

\author{
Address: ${ }^{1}$ Instituto de Histología y Patología, Universidad Austral de Chile, Valdivia, Chile, ${ }^{2}$ National Institute of Environmental Health Sciences \\ (NIEHS, NIH), Research Triangle Park, NC, USA and ' ${ }^{2}$ ivision of Oncology, Department of Cancer Biology, Institute of Medical Science, \\ University of Tokyo, Japan \\ Email: EM Rodríguez* - erodrigu@uach.cl \\ * Corresponding author
}

from $\left.5\right|^{\text {st }}$ Annual Meeting of the Society for Research into Hydrocephalus and Spina Bifida Heidelberg, Germany. 27-30 June 2007

Published: 20 December 2007

Cerebrospinal Fluid Research 2007, 4(SuppI I):S25 doi:I0.I I86/1743-8454-4-SI-S25

This abstract is available from: http://www.cerebrospinalfluidresearch.com/content/4/SI/S25

(c) 2007 Rodríguez et al; licensee BioMed Central Ltd.

\section{Background}

The subcommissural organ (SCO) differentiates early in ontogeny and remains fully active during the entire life span. It secretes glycoproteins into the cerebrospinal fluid (CSF) flowing through the Sylvius aqueduct (SA); these proteins either assemble to form Reissner fiber (RF), or remain soluble in the CSF and circulate throughout the CSF compartments. Overholser et al. (1954) have demonstrated that offspring littered by rats maintained on a diet deficient in folic acid and/or Vitamin B12 lack a SCO and develop hydrocephalus. This led them to propose that a dysfunction of the SCO during development leads to stenosis of the SA and hydrocephalus. We have investigated several animal models in which the SCO would play a role in the pathogenesis of hydrocephalus. We have now performed a comparative analysis of the changes occurring in the SCO-RF complex of these animal models, with the aim to find a landmark common to all hydrocephalic animals that might help to unfold the mechanism of SCO-dependant hydrocephalus.

\section{Materials and methods}

A comparative study of the SCO-RF complex and SA of five animal models characterized by a dysfunction of the SCO and development of hydrocephalus was carried out. Conventional light and electron microscopy and immunocytochemistry were applied.

\section{Results}

Model 1. Immunological blockage of RF formation by maternal transfer of antibodies against RF-glycoproteins: undamaged and secretory active SCO, missing RF, stenosed SA and moderate hydrocephalus. Model 2. hyh mice with a point mutation of $\alpha \mathrm{SNAP}$ gene: undamaged and secretory active SCO, missing RF, obliterated SA and severe hydrocephalus. Model 3. HTx rat: subcommissural portion (two distal thirds) of SCO missing, supracommissural portion (rostral third) of SCO secretory active, RF absent, obliterated SA and severe hydrocephalus. Model 4. Transgenic mice deficient in transcription factor RFX4v3: subcommissural portion of SCO missing, supracommissural portion of SCO secretory active, RF absent, patent SA and moderate to severe hydrocephalus. Model 5. fyn knockout mice: subcommissural portion of SCO missing, supracommissural portion of SCO secretory active, RF absent, SA with an abnormal shape and severe hydrocephalus.

\section{Conclusion}

1. The SCO is formed by two zones: the subcommissural and the supracommissural portions. 2. Differentiation of both zones would be controlled by different genes. 3 . The subcommissural portion of the SCO is essential for RF formation. Mutant and transgenic animals lacking this portion, although still have a secretory active 
flow of CSF throughout SA. 6. Absence of RF could cause SA obliteration or a turbulent CSF flow through SA what, in turn, would lead to hydrocephalus. Supported by Fondecyt 1030265 (Chile), the Intramural Program of the NIH, NIEHS (USA), and MEXT (Japan).

Publish with Bio Med Central and every scientist can read your work free of charge

"BioMed Central will be the most significant development for disseminating the results of biomedical research in our lifetime. " Sir Paul Nurse, Cancer Research UK

Your research papers will be:

- available free of charge to the entire biomedical community

- peer reviewed and published immediately upon acceptance

- cited in PubMed and archived on PubMed Central

- yours - you keep the copyright

Submit your manuscript here:

http://www.biomedcentral.com/info/publishing_adv.asp 